CEP Discussion Paper No 625

March 2004

\title{
Is There an Impact of Household Computer \\ Ownership on Children's Educational Attainment in Britain?
}

John Schmitt and Jonathan Wadsworth

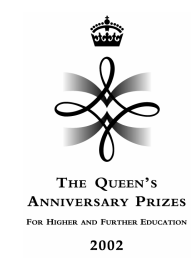




\begin{abstract}
If personal computers (PCs) are used to enhance learning and information gathering across a variety of subjects, then a home computer might reasonably be considered an input in an educational production function. Using data on British youths from the British Household Panel Survey between 1991 and 2001, this paper attempts to explore the link between ownership of a home computer at ages 15 and 17 and subsequent educational attainment in the principal British school examinations taken at ages 16 (GCSEs) and 18 (A levels). The data show a significant positive association between PC ownership and both the number of GCSEs obtained and the probability of passing five or more GCSEs. These results survive a set of individual, household, and area controls, including using other household durables and ।"futurel" PC ownership as proxies for household wealth and other unobservable household level effects. Home computer ownership is also associated with a significant increase in the probability of passing at least one A level conditional on having passed five and increase in the probability of successfully completing three or more A levels, conditional on having passed at least one A level.
\end{abstract}

JEL Classifications: I2, J2, J13, J24

Keywords: Human capital, Economic Impact, Personal Computers

This paper was produced as part of he Centre's Education and Skills Programme. The Centre for Economic Performance is financed by the Economic and Social Research Council.

\title{
Acknowledgements
}

BHPS data used by permission of ONS, made available through the ESRC Data Archive at the University of Essex. The 1st draft of this paper was given at the NIESR conference on IT, London, October 2001.

John Schmitt is a Senior Research Associate with the Center for Economic and Policy Research. Jonathan Wadsworth is a lecturer at Royal Holloway Colle ge London and a Senior Research Fellow at the Centre for Economic Performance, London School of Economics.

\author{
Published by \\ Centre for Economic Performance \\ London School of Economics and Political Science \\ Houghton Street \\ London WC2A 2AE
}

All rights reserved. No part of this publication may be reproduced, stored in a retrieval system or transmitted in any form or by any means without the prior permission in writing of the publisher nor be issued to the public or circulated in any form other than that in which it is published.

Requests for permission to reproduce any article or part of the Working Paper should be sent to the editor at the above address.

(C) John Schmitt and Jonathan Wadsworth, submitted 2004

ISBN 0753017504 


\section{Executive Summary}

If personal computers (PCs) are used to enhance learning and information gathering across a variety of subjects, then a home computer might reasonably be considered as a potential means to enhance educational attainment. Using data on British youths from the British Household Panel Survey between 1991 and 2001, this paper attempts to explore the link between ownership of a home computer at ages 15 and 17 and subsequent educational attainment in the principal British school examinations taken at ages 16 (GCSEs) and 18 (A levels). Our results show a significant positive association between PC ownership and both the number of GCSEs obtained and the probability of passing five or more GCSEs and, more weakly, that the frequency of PC use appears to be positively correlated with these educational outcomes. Home computer ownership is also associated with a significant increase in the probability of passing at least one A level conditional on having passed five and increase in the probability of successfully completing three or more A levels, conditional on having passed at least one A level. These results are robust to a set of controls for individual, household and area characteristics, including household wealth proxies and, (for A levels), prior educational attainment of the student. When we use the panel nature of the data set to control, additionally, for future ownership of a PC as a proxy for unobservable household characteristics, the PC effects on remain (but reduced in statistical significance for the A level results' sample) and the future PC variables are statistically insignificant. These findings suggest that the PC effects we observe may reflect a direct role for PCs in the educational "production function" for teenagers, though we would welcome more controlled experimental evidence on this issue. If confirmed, PC ownership could have economically and economically important effects on educational and, by extension, subsequent economic outcomes. If so, then policy makers may need to consider the implications of these effects for economic and social inequality. 


\section{Introduction}

A large body of research has documented the emergence and persistence of a "digital divide" in household ownership of personal computers (PC) in the United States, Britain and elsewhere. ${ }^{1}$ PC ownership is concentrated in richer households, with the ownership gap between rich and poor widening over the last decade. Research attempting to link PC ownership directly to other economic or social outcomes, has tended to focus on the effect of computers on the earnings of adults (see, Krueger (1993), DiNardo and Pischke (1997), Entorf, Gallac and Kramarz (1999), Anger and Schwarze, (2002)). This paper attempts to explore the link between PC ownership and a different but important social and economic outcome, children's educational attainment.

If PC's are used for information gathering and learning across a variety of subjects, or if PCs help to increase individual experience of general computer skills, then a home computer might be reasonably considered an input in an educational production function. This could then, theoretically, enhance children's demand for education and their future productivity. Increased familiarity with a computer, increased frequency of internet use, and computer-based learning programs could all help boost educational attainment and examination performance. A simple search of the World Wide Web, for example, shows that many commercial study guides specific to the British high-school-level examinations we study here are available in $\mathrm{CD}$ format in shops or can be downloaded directly from the internet. Access to the many online exam-preparation sites, which provide details and interactive tests, could also have a positive effect on examination performance. Many examinations now require coursework, which can be completed in a student's own time and are therefore open to influence of all the resources provided by ownership of a computer. ${ }^{2}$ In this way, home computers may complement any effects of PCs used in schools (see Angrist and Lavy (2002) for a recent study of the impact of computers in schools on educational attainment, which finds little effect of computer-aided instruction on test scores in Israeli middle and elementary schools).

In what follows, we use data from the British Household Panel Survey (BHPS) to compare the educational achievement of 16- and 18-year-olds living in households with and

\footnotetext{
${ }^{1}$ See, among others, Kominski and Newburger (1999) and U.S. Department of Commerce (2000, 2002); see Office of National Statistics (2002) and Office of the e-Envoy (2002), Schmitt and Wadsworth (2002) for Britain and an explicit comparison of ownership patterns in Britain and the United States; see Haisken-DeNew and Schmitt, (2001) for Germany.

${ }^{2}$ For example, the BBC has an on-line revision site aimed at schools http://www.bbc.co.uk/schools/revision/.
} 
without a PC. The British data are particularly well-suited to this research because they are one of the few nationally representative data sets, of which we are aware, that contain information on: home computer ownership and its year of acquisition alongside educational outcomes. $^{3}$ Relative to the United States, the British educational system provides more potential observation points on educational outcomes. With British data, we can measure success in reaching a minimum level of achievement in nationally administered examinations generally taken at age 16 - the General Certificate of Secondary Education, (GCSEs), a higher level of achievement in the same examinations at 16 (related to the number of GCSE exams passed), and the level of achievement in national tests generally administered at age 18 for those who remain in school, the General Certificate of Education: Advanced, (A-levels). The same data also allow for a large range of household and individual controls that are necessary to attempt to separate out any true "PC effects" from those simply correlated with PC ownership, such as household income or parental background, which could also influence educational outcomes of children in the household.

To summarize our main results, once we control for a variety of household characteristics correlated with PC ownership and educational outcomes, we find mixed support for the view that PC ownership is associated with improved educational achievement. PC ownership does not appear to affect the probability that children "get" any GCSEs, but does appear to have an important positive association with the number of GCSEs levels successfully completed. We also find that PC ownership is associated with successfully completing at least one and at least three A levels. These effects appear to be robust to a series of tests that we use to try to control for other influences on educational outcomes that may be correlated with PC ownership. Since completing five or more GCSEs is an important marker for acceptance on to A levels and completion of three or more A levels is a standard prerequisite for university admission, our results suggest that PC ownership may have potentially important social and economic benefits for children.

The next section of the paper gives a brief summary of the relevant features of the British educational system. The third section describes the BHPS data that we use here. The fourth section presents the results of the various estimation procedures. The final section concludes.

\footnotetext{
3 The GSOEP used by Anger and Schwarze (2002) contains a question on home computer ownership and year acquired for 1997, which could in principle be used to carry out a similar study.
} 


\section{The British Examination System}

All children living in England and Wales must complete eleven years of education, which begin at age five and end at age sixteen. The school year begins in September and ends in July. Children can leave school in the July following their $16^{\text {th }}$ birthday. ${ }^{4}$ The British system has no compulsory examination at the end of the eleventh year of schooling, but the vast majority of students sit a series of GCSE examinations in June of their final compulsory year. ${ }^{5}$ Each academic subject - History, for example- has its own examination. Students typically sit about nine exams, which are graded from $A^{*}$ (highest) to $G$ (lowest). Around $10 \%$ of students get the highest grades of $\mathrm{A}^{*}$ or $\mathrm{A}$ and another $10 \%$ get the lowest grades of $F$ or $\mathrm{G}^{6}$. In 1997, the UK government set a target aimed at ensuring that at least $50 \%$ of 16 year olds obtained five or more GCSEs at grade C or above. This target was first met in $2002 .^{7}$

After 16, around $70 \%$ of individuals remain in full-time education until the age of 18 , either in the same secondary schools or in Further Education colleges. At 16, individuals decide to pursue either a series of vocational qualifications (National Vocational Qualifications, NVQs), or the more academic-orientated two-year Advanced (A) level courses, which end in exams, typically at age 18. A-level examination results are the primary means of determining entry into university. Students typically require five or more GCSE passes (at grade $\mathrm{C}$ or higher) to be considered for Alevel entry. Once accepted, individuals usually choose three subjects to study for the corresponding A-level examinations. Three A level passes will normally guarantee entry to university, though the particular university and course of study depend on the grade achieved in each A level examination.

We compare students' educational achievement at two points along this educational path (GCSEs and A levels). Within each of these two points, we consider a basic level of achievement (any pass with a grade of $\mathrm{C}$ or higher), as well as, more difficult standards based on the number of passes.

\footnotetext{
${ }^{4}$ Since the school year begins in September and ends in July, pupils can, in principle, leave at age 15, if their birthday falls between the end of one school year and the beginning of the next.

${ }^{5}$ About $5 \%$ of students leave school without sitting GCSE examinations or after failing all those exams for which they entered.

6 There are also different "tiers" within GCSE's. The range of possible grades awarded is partly dependent on which tier the child takes. There is also the possibility of achieving a "U" grade if the paper is failed. Around $2 \%$ of pupils receive grade U, on average, in any one subject. http://www.bstubbs.co.uk/5a-c.htm

${ }_{7} \mathrm{See}$, for example, the website http://www.literacytrust..org.uk, which provides many summary statistics on attainment at age 16 and 18 .
} 


\section{Data}

We draw our data from the BHPS, which is a longitudinal survey of all the occupants living in a sample of some 5,000 randomly selected, nationally representative British households. The BHPS is conducted in the fall of each year, beginning in 1991 and ending, currently, in the year 2001. The BHPS was designed originally as an annual survey of each adult member (aged 16 and over) of a household, yielding a total of approximately 10,000 individual interviews in each wave. If individuals split-off from their original households, all adult members of the new households are followed and interviewed. Thus the sample should remain broadly representative of the population of Britain as it changes. Detailed information on each occupant aged 16 and over, including past and subsequent examination performance is collected in each wave. In addition, the age and gender of any children in the household under the age of 16 is also monitored. There are around 150 individuals who turn 16 in each wave of the survey. We therefore pool all 16 and 18 year olds across the last 10 waves of the survey to create our sample data sets. Sixteen and 18 year olds in the first wave are omitted since there is no information for these individuals on their circumstances one year earlier.

The data set contains information on whether the individual obtained any GCSEs at grades $\mathrm{C}$ or above, the number of GCSE passes at grade $\mathrm{C}$ and above, (but not the actual grade obtained), whether the individual obtained any A levels and if so, the number, but not the grade, of A level passes. Since the level of educational attainment is asked in each year of the survey, we can identify those who took the exam at 16 in the BHPS survey that corresponds to either their sixteenth or seventeenth birthday, depending on when their birthday falls in relation to the BHPS interview date. We can also identify those pupils who took GCSEs when they were 15, (we will capture them in the BHPS survey that corresponds to their sixteenth birthday). If the individual gets a GCSE grade lower than C, it is not uncommon for the student to repeat the examination, particularly in the key subjects of Mathematics and English, the following year. These additional measures of examination success, while recorded in subsequent waves of the data, do not appear in our dependent variables. For most individuals in the data, we therefore essentially observe a "one-off" experiment.

We use a similar method to define the sample of "18 year olds" and their possession of A levels. The longitudinal nature of the data means that the same individual can appear in both our "16 year old" and our "18 year old" samples and about 70\% of individuals in the 
data do appear in both samples. The data set contains no other information on children's ability (such as the nationally administered aptitude tests taken by all 14 year olds in Britain). Month of birth also determines which third of the school year the child begins school. This then influences the total amount of time spent in school and, potentially, earnings as suggested by Angrist and Krueger (1991). We therefore include relevant controls for season of birth in what follows. ${ }^{8}$

For our purposes, the main advantage of the BHPS is that it is one of the few data sets that also provides information that enables us to determine if and when the household acquired a PC. The BHPS asks households, not individuals, about their ownership of various consumer durables, including PC's, in each wave of the survey. Specifically, the BHPS asks whether "the household owns or rents a personal computer, even if used only for games, but only if it has a keyboard." The BHPS includes in this definition computers used for business purposes by the self-employed, but excludes those provided by employers for work at home. We can therefore determine whether the household owned a personal computer in the year(s) before the child sat GCSE or A-level examinations. This feature is the basis for the construction of the main explanatory variables of interest here, "PC15" and "PC17" (a dummy variable taking the value one if the household owned a computer the year before the relevant examination took place and zero otherwise). ${ }^{9}$ Since the BHPS establishes PC ownership in each wave, recall bias should not be a problem (though any measurement error at the time of survey - for example, when a respondent claims ownership of a PC when, in fact, the household does not have one - will still bias the results toward zero in the usual way). ${ }^{10}$ Since ownership questions are asked in each wave, we can also identify the age of the youth when the household first took ownership of the PC and hence derive a "years of PC ownership" variable, which could help measure any effect of cumulative PC experience on subsequent performance.

Beginning with the fourth wave (1995), the BHPS also contains a separate set of questions asked to all 11 to 15 year old household members. Beginning in 1997, this additional survey includes a categorical question on the frequency of home computer use among 11 to 15 year olds, excluding time spent on computer games. We can match the answers to these questions at age 15 to around one third of our 16-year old sample. For this

\footnotetext{
${ }^{8}$ Since the school year runs from September to August, children born between September and December begin school in September, six months earlier than those born between May and August of the following year.

9 The BHPS contains no information on whether any parent uses a computer at work.

10 See Entorf, Gallac and Kramarz (1999) for a discussion of these issues in their study of computers in the workplace.
} 
sub-sample we construct five dummy variables, splitting 16-year olds according to whether the individual: (a) made no use of a PC in a household that had one; (b) used a PC 1-2 days a week; (c) 3-4 days a week; (d) most days; or (e) did not have a computer at age 15. We can then test whether frequency of use, as well as ownership, is associated with educational attainment. For this sub-sample, we also have information on the individual's attitude to school work, and whether they were bullied at school at age 15, which we include as additional controls, to try to account for some aspects of individual heterogeneity.

The potential control variables are measured in the year before the relevant examination took place and are then mapped onto the individual. We match information relating to household characteristics, and local area circumstances to each child in the data set using the household and local authority identifiers in the data. If a child subsequently leaves the parental home, we follow the individual to the new household, which by the BHPS design is incorporated into the survey. Since Scotland has its own examination system that differs in important ways to the system in England and Wales, we drop all Scottish observations from the sample. From 1999 onward, in an effort to improve the accuracy of information on Wales, the BHPS supplemented the Welsh sample, boosting it relative to the first eight years of the survey. We incorporate the Welsh supplement in our analysis, but include a set of year dummy variables, one for each wave of the data, and 18 area dummy variables, including one for Wales, in all regressions. When indicated, the regressions also contain a set of control variables for household and parental background as well as the characteristics of the 16 and 18 year olds in the sample. In all, we have around 1,450 observations with a full set of control variables on 16 year olds, of which $78 \%$ come from different households. ${ }^{11}$ We have about 1,500 complete observations on 18 year olds.

\section{Estimation}

In this section, we use our sample of youths from the BHPS to estimate the impact of PC ownership on six educational outcomes: (1) successful completion of any GCSE at grade C or higher; (2) the total number of GCSE passes; (3) successful completion of five or more

\footnotetext{
11 This means that including household fixed effects will almost saturate any estimates, since the effect of PCs is identified only by the population of households who have a change in computer ownership between siblings becoming 16.
} 
GCSEs at grade C or higher; (4) successful completion of one or more A levels; (5) the number of A levels; and (6) successful completion of three or more A levels.

The basic equation we consider is: $\operatorname{Pr}\left[\operatorname{Ed}_{i j}=1\right]=a+B C$ Computer ${ }_{i}+X_{i} B+u_{i}$ where $\mathrm{Ed}_{\mathrm{i}}$ is a variable measuring individual i's attainment of education level $\mathrm{j}$; "Computer" is a dummy variable taking the value one if the individual lived in a household with a computer prior to taking the relevant examination and zero otherwise; $\mathrm{X}$ is a vector of individual, household and area controls. To allow for the potential effect of increased experience of computer use on educational attainment, we also include years of computer ownership and (for a sub-sample only) frequency of use in the year before the examination was taken, alongside or instead of the PC ownership dummy variable:

$$
\operatorname{Pr}\left[\mathrm{Ed}_{\mathrm{ij}}=1\right]=\mathrm{a}+\mathrm{BComputer}_{\mathrm{i}}+\text { ?Experience }_{\mathrm{i}}+\mathrm{X}_{\mathrm{i}} \mathrm{B}+\mathrm{u}_{\mathrm{i}}
$$

Since each individual takes the relevant examination only once, there is no within-group variation in the dependent variable over time. This precludes the use of difference-indifference or other panel data estimation techniques to account for any unobservable effects that may be correlated with PC ownership and examination performance. Any PC effect is therefore identified by conditioning on observables and we therefore include in the $\mathrm{X}$ vector many individual, household, and local area controls assuming, then, that any remaining, unobservable characteristics enter into a well-behaved disturbance term (we perform several tests of this assumption below). Since the PC is measured at household rather than individual level, we adjust the standard errors in the estimation to take account of this household-level clustering. The full set of explanatory control variables, measured in the year before the relevant examination took place unless otherwise specified, is outlined in Table A1 of the appendix.

\section{Results}

We begin, in Table 1, with a summary of the overall trends in educational attainment and PC ownership in our data set. Over the sample period, PC ownership rates for the population as a whole doubled, from about $29 \%$ of all individuals in 1991 to about $57 \%$ in 2001. In households containing 16 year olds, the incidence of PC ownership is always higher than in the rest of the population, and ownership rates for this group of households rose steadily, from just over half $(52 \%)$ in 1991 to almost three fourths $(73 \%)$ of households with a 16- 
year-old present in 2001. PC ownership is slightly less common among households with an 18-year-old, but these households showed the same strong upward trend in ownership between 1991 and 2001. Over the same period, the overall level of GCSE and A-level attainment also rose. By 2001, around 75\% of the sample of 16-year-olds had at least one GCSE at grade $\mathrm{C}$ or higher and about $55 \%$ had managed five or more GCSEs passes and about $48 \%$ of the 18 -year-olds had at least one A level.

\section{GCSEs}

Panel (a) of Table 2 presents our first set of results on the impact of PC ownership on obtaining any GCSEs at grade $\mathrm{C}$ or higher. The first column reports marginal effects from a probit equation of GCSE attainment at age 16 conditional on PC ownership at age 15, with controls only for the wave of the BHPS in which the individual was observed at age 16 . In this simple equation, PC ownership at 15 raises the likelihood of receiving GCSEs at 16 by 15.1 percentage points (statistically significant at the $1 \%$ level using robust standard errors). Adding a quadratic for real household income, equivalised by the square root of the number of individuals in the household, (column two), cuts the estimated PC effect to 9.9 percentage points. Column three adds other housing level controls, including additional possible household wealth proxies - number of rooms and housing tenure - and other controls for mother and father's education, mother and father's age, marital statues of parents, number of dependent children living in household, whether household had moved in past 12 months, parental involvement in school parent-teacher association, and the religious outlook of parents. These variables reduce the size of the estimated PC effect considerably and the effect is no longer statistically significant. Column four adds individual-level controls for trimester of year in which child began school, gender, ethnicity, sibling order of the child, and health status of the child. Column five adds area level variables for region, school type (the default category is the modal form or British school, the comprehensive), and parental perception about whether the neighbourhood is "bad." These additional controls have little further effect on the economic magnitude or statistical significance of PC ownership. Table A2 in the Appendix gives the full set of estimates from this regression and shows that age of mother, sibling order and school type are some of the main driving factors underlying the probability of having any GCSEs. 


\section{Number of GCSEs}

We next count the number of GCSE passes at grades $\mathrm{A}^{*}, \mathrm{~A}, \mathrm{~B}$, or $\mathrm{C}$ and use this as an alternative dependent variable. We also define a binary dependent variable taking the value one if the individual obtained five or more GCSEs at grade $\mathrm{A}^{*}$ to $\mathrm{C}$ and zero otherwise. Five or more GCSEs at grade $\mathrm{C}$ or higher is the usual cut-off point for entry into A levels and the further two years of non-compulsory school education that this entails. A levels generally put children on a track to attend university rather than some other form of after-secondary education or no after-secondary education at all. Successful completion of five or more GCSEs is also an official government target for national educational attainment. We estimate both these alternative regressions on the subset of individuals who obtained at least one GCSE at grade $\mathrm{C}$ or above, to net out any effect of reaching this first threshold. In so doing, Table 1 indicates that we are testing for PC effects in the top $70 \%$ of the educational attainment distribution at age 16 .

Panel (b) of Table 2 repeats the exercise in panel (a), now using the number of GCSEs as the dependent variable conditional on obtaining at least one GCSE, (and using ordinary least squares, rather than probit, given the change in the nature of the dependent variable). Even after including the full set of individual, household, and area controls (column five), PC ownership is associated with a positive, statistically significant increase in the number of GCSEs, equivalent to about half an additional GCSE. ${ }^{12}$ Adding variables to control for educational conditions in local authorities (column six), which lowers the sample somewhat, has no impact on the size or significance of the estimate.

Panel (c) of Table 2 suggests that PC ownership may also have an economically important and statistically significant, positive impact on the probability of attaining five or more GCSEs grade $\mathrm{C}$ or higher, a national educational goal and important milestone for further education. Adding successive levels of controls (columns two through five) reduces the economic impact to about nine percentage points, but the effect remains statistically significant at the 5\% level. Again, adding controls for local education authority characteristics (column six) does not alter the conclusions.

\footnotetext{
12 Table A2 in the Appendix shows that gender, mother and father's level of education, and school type have larger overall effects on the number of GCSEs obtained.
} 


\section{Robustness Tests}

Even though the regressions in column five of Table 2 control for a broad list of individual, household, and local-area characteristics, PC ownership may still simply be acting as a proxy for unobserved characteristics, such as household wealth, which may be positively correlated with both PC ownership and higher educational attainment ${ }^{13}$. As a first test, Table 3 reports the results from a new set of equations. These equations are modelled on those in Table 2, but, here, we have substituted dishwasher, tumble drier and car ownership for the PC ownership variable in Table 3. These alternative household durables may also proxy unobservable household effects, especially wealth effects, that are not picked up in the comprehensive list of controls. At the same time, we might not expect these other consumer durables, in and of themselves, to be important inputs into an educational production function. ${ }^{14}$

With only basic controls, dishwasher or car ownership do indeed appear to have as large an impact on number of GCSEs obtained as owning a PC (see columns one and five); while tumble driers appear to have an insignificant negative impact (column three). After we include the full set of controls (columns two, four and six), the apparent educational effects of dishwashers, driers and cars fall substantially and are no longer statistically significant. In the last column of Table 3, we report the results from a regression that includes a full set of individual, household, and area controls, together with all three of these other household assets and the original PC-ownership variable. Even after we include the other household assets, which should act as proxies for unobserved wealth effects, PC ownership still raises the number of GCSE passes by an amount that is very close to the impact reported earlier in Table 2, column five, (about half a GCSE, significant at the 1\% level). Meanwhile, none of the other household durables is statistically significant.

The pattern of results for five or more GCSE passes is similar. The inclusion of cars and the other household durables does not eliminate the large, well-defined effect of PC ownership at 15 on attainment of five or more GCSEs. In the last column of Table 3, which includes the full set of individual, household, and area controls, PC ownership is associated with about a 9 percentage-point increase in the probability of obtaining five or more GCSEs,

\footnotetext{
${ }^{13}$ Including household fixed effects in addition to the full set of controls, the coefficients and standard errors on the PC ownership variable at 15 for the 3 different dependent variables are, respectively $-0.115(0.150) ; 0.332$ (0.535); 0.035 (0.082).

${ }^{14}$ DiNardo and Pischke (1997) employ a similar strategy in their analysis of the returns to computers in the workplace. They compare use of low-tech pencils and use of high-tech computers on the job in otherwise standard wage equations.
} 
very close to the estimated effect in the last column of Table 2, which does not have controls for other household durables.

Taken together, the results in Table 3 suggest that the PC effect may not simply be acting as a proxy for unobserved household wealth. Nevertheless, other unobserved individual and household level influences may still be at work. As an additional test, we also examine the impact "future" PC ownership on educational attainment. Bell (1996) and Anger and Schwarze (2002) exploit the longitudinal nature of their data sets to introduce future PC use into their studies of the impact of PC use at work on wages. In the present context, if the observed effect of PCs on GCSE attainment reflects unobserved characteristics of households that buy PCs - rather than real educational returns to PC ownership- children in households that purchased a PC shortly after the child took GCSEs should have similar educational outcomes to those children that actually had a PC before taking GCSEs.

Table 4 tests the impact of "future" PC use on "present" GCSE results. The first column of the table simply reproduces the coefficient estimates from a regression with the full set of controls, including other household durables, which originally appeared in the last column of Table 3 . The second column of the table uses instead a binary variable that takes the value one if the household of the child had a PC at the ages of 16 to 18 - that is, after he or she took the exam. ${ }^{15}$ The effect is always statistically insignificant from zero. If we include both the PC at 15 and future PC variable the PC at 15 effect remains significant and close to the original estimate in column one ${ }^{16}$, while the future PC variable remains insignificant. However the confidence interval around the PC at 15 estimates do include the point estimates on the future PC variable.

In the fourth column of Table 4, we examine earlier PC ownership. If PC ownership is simply a marker for certain types of families, rather than a true input in the child's educational production function, earlier PC ownership might also have an effect on subsequent GCSE results. ${ }^{17}$ Earlier PC ownership, however, has no impact on the number of GCSE passes, and, once again, the effect of PC ownership at 15 is statistically significant with a magnitude close to earlier estimates. Including all three of the age-acquired PC variables, leaves only the effect of PC ownership at 15 positive and significantly different from zero, though the

\footnotetext{
${ }^{15}$ All those aged $16 \&$ with a computer at the time they took GCSEs will be coded with a value 1 for the PC15 variable and a value 0 for the future $\mathrm{PC}$ variable.

16 These results differ markedly from those of Anger and Schwartz (2002), who find a strong effect of "future" PC use on current wages. Our findings that PCs appear to have an impact on educational outcomes do not imply that PCs should have any impact on productivity in a different setting.

${ }^{17}$ Though, households that gain and then lose a computer (through lack of interest, financial hard times, theft, etc.) could arguably be qualitatively different from households who obtain a computer later and hold on to it.
} 
confidence interval around this estimate incorporates the point estimates on the other (insignificant) PC variables. ${ }^{18}$

In the bottom panel of Table 4, as with the number of GCSE passes, PC ownership at 16 to 18 (column two) or 16 (column three) has no effect on the probability of obtaining five or more GCSEs and little impact on the size or statistical significance of PC ownership at age 15. The inclusion of earlier PC ownership, however, while not statistically significant itself, reduces the statistical significance of the $\mathrm{PC}$ at 15 variable to the point where $\mathrm{PC}$ ownership at 15 is only statistically significant at the $10 \%$ level in columns four and five. It would seem then that the performance of children who never had a PC may be different from those who acquired a PC at some time.

\section{Frequency of Use}

We perform one final test to try to distinguish between a true PC effect on educational outcomes and a spurious effect based on PC ownership acting as a proxy for unobserved household characteristics. Implicit in the analysis so far is the assumption the PC ownership is a good proxy for actual use of computers, which is presumably the channel through which computer ownership improves educational outcomes. Since 1997, the BHPS has asked all 15year-olds about how many days each week they used a home computer if one is present in the household. Children could respond: no days, 1-2, 3-4, or most days. This gives us one way to test the effect of computer use at the intensive margin. Another way is to count the number of years of PC ownership using the information in the data set. Columns 14 and 7 in Table 5 add years of experience to the PC at 15 variable for the three dependent variables. While positive, the years of experience variable is never significant.

As a point of reference, columns 2, 5 and 8 in Table 5 give the PC at 15 effect controlling for the all individual, household, and area variables as above, including household assets, for the sub-sample of households asked about computer use frequency at age 15 . We also include additional controls for the child's attitude to schoolwork and whether they were being bullied at school, available in the same youth supplement as the extra PC frequency information. The coefficient estimates on PC at age 15 in these basic specifications are close to those in the full sample, though, because of the smaller sample size, the standard errors in

\footnotetext{
${ }^{18}$ The slightly higher coefficient is not surprising given that the excluded group in the last column are children in households that never owned a PC; in the base regression in column one, the excluded group includes households that owned a PC at at least some point in time during the sample period.
} 
the sub-sample are much larger. The following columns in the table give the estimated impact on educational outcomes of different intensities of computer use. For successful completion of any GCSEs (columns one and two), a case where PC at 15 appeared to have no impact on educational outcome, the intensity of computer use appears to track educational outcomes closely. Children who live in houses with computers, but who never use those computers, are actually less likely (by about 20 percentage points) to complete at least one GCSE than children in houses that don't have computers; those who use computers once or twice a week have about the same probability as those in houses without computers; children who report using a computer 3-4 times a week have a 10 percentage point advantage; and those who say they use computers "most days" each week, a 13 percentage point advantage. The results are not quite as clear cut for the second two educational outcomes using the smaller sample of those with both the frequency variable and who had at least one GCSE, but nevertheless still suggest that more frequent PC use is associated with better educational outcomes. Taken together, the results in all three cases provide some support for the view that, within households that have computers, children who use computers more fare better. To the extent that this is true, these results, therefore, reinforce the findings in tests based on other household assets and "future" PC use that PC ownership s simply acting as a proxy for unobserved household characteristics. ${ }^{19}$

To summarize the results for GCSEs, the data show a robust, economically and statistically significant, impact of PC ownership on the number of GCSEs (about half a GCSE) and on the probability of passing five or more GCSEs (about 10 percentage points). These results survive a full set of individual, household, and area controls, including using other household durables as proxies for household wealth. "Future" PC ownership does not predict earlier educational outcomes, which is consistent with the view that the PC ownership effect is not simply capturing some other unobserved characteristics of households. That more frequent use of PCs appears to be also associated, at least weakly, with better GCSE results provides some further support for the view that PCs may have a direct, causal effect on children's educational attainment at some points in the distribution of attainment.

\footnotetext{
${ }^{19}$ Of course, the tentative results in Table 5 are also consistent with the hypothesis that frequent PC use is a marker for students who are likely to perform well in GCSEs, and that actual PC use has no causal impact on examination results. Since the natural "experiment" studied here is undertaken only once for each child, it is difficult to account for any residual, unobserved individual heterogeneity and our results should always be interpreted with this in mind.
} 


\section{A-levels}

The BHPS data also allow us to look separately at the impact of PC ownership at age 17 on the attainment of "A-levels," typically at age 18. Table 6 reports results for the probability of A level receipt, the number of A levels obtained, and the probability of gaining 3 or more A levels, (a usual but not sufficient condition for attending university), all conditional on PC ownership at age 17. The set of controls are the same as those used for the 16-year-old sample in Table 3, column 8, including household ownership of cars, VCRs, and dishwashers, now measured when the individual was 17 rather than 15 . The first column shows a strong, statistically significant, impact of PC ownership at age 17 on subsequent attainment of A levels. PC ownership at age 17 raises the likelihood of attaining A-levels among all 18-year-olds by about 12 percentage points. If we condition on the subset of youths who are, in principle, eligible to take A-levels, that is those with five or more GCSEs (column 2), then the PC effect falls to around 11 points, but remains significant. Among the third of 18 year olds with at least one A level pass, household PC ownership at age 17 seems to be associated with around one quarter of an extra A level (column 3). Using three or more A levels as dependent variable, (column 4), the PC effect is estimated to be about 15 percentage points.

One could argue that household computer ownership might be a proxy for ability of or interest in education of the student. To net out some of these effects we include an additional control for prior level of educational attainment in these regressions, namely the number of GCSEs at grades $A^{*}-\mathrm{C}$, for the sub-set of individuals who can be matched ${ }^{20}$. These estimates are given in Panel B of Table 6. Including GCSE score does reduce the effect of PC on obtaining any A levels and the estimated effect of this control variable, (not shown), is positive and highly significant. However significant PC effects remain for the estimates of the number of A levels obtained, (of around one quarter of an A level) and the probability of getting three or more A levels, (of around 16 percentage points).

In Table 7, we test whether "future" PC ownership has an effect on A level results. The table shows four separate regressions (with controls analogous to those in the last column of Table 4 for GCSEs), one for each of the dependent variables in Table 6. We again combine future PC owners at ages 18 to 20 into a single dummy variable. The PC effect remains

\footnotetext{
${ }^{20}$ We are unable to do this for the GCSE sample because there is no information on any tests taken before age 16 in the data set. Some of the A level sample have no GCSE information because they enter the data set after the age of 16 .
} 
positive and significant in the presence of the future PC variable. The future PC variable itself is positive and significant only in column 1, for the probability of gaining any A levels ${ }^{21}$. We cannot discount the possibility then that unobserved heterogeneity may influence the probability of A level receipt.

The dependent variable here includes both the decision to stay on and A level success, allied to the fact that the future PC variable is not significant in the other columns which condition on A level entry. It seems then that unobserved heterogeneity is more likely to affect the decision to stay on and take A levels. The point estimates suggest ownership of a $\mathrm{PC}$ at 17 is associated with a quarter point increase in the number of $\mathrm{A}$ level passes and a 16 point increase in the probability of passing 3 or more A levels. Panel B conditions additionally on prior educational attainment. The point estimates of the PC effect are similar to those in Panel B, but estimated with less precision. If we add prior ownership of a PC, the PC at 17 effect is much less precisely estimated relative to the (much smaller) default category of those who never owned a PC. ${ }^{22}$

\section{Conclusion}

Ownership of home computers is highly unequal across income, education, racial and other groups in both the United States and the United Kingdom. To date, most of the discussion of the digital divide has taken PC inequality to be problematic at face value, (a view that we generally share). The analysis here, however, attempts to begin to assess the social and economic cost of PC inequality by measuring the impact of PC ownership on educational outcomes of teenagers. Gauging the impact of PC ownership on educational attainment, however, is not straightforward because of difficulties inherent in separating out any "real" educational effects of PCs from hard-to-observe factors that may lead both to PC ownership and positive educational outcomes.

In our tests of PC ownership on six types of educational outcomes, we find evidence of a positive, statistically significant, association between ownership of a PC and the number of GSCE grade $\mathrm{A}^{*} \mathrm{C}$ and also the number of $\mathrm{A}$ level passes, conditional on a variety of individual, household and area characteristics. More weakly, the frequency of PC use appears

\footnotetext{
21 If we use the future PC variable on its own, it is not significant.

22 The BHPS does not ask 17-year-old children about the frequency of their use of PCs, so we cannot perform an exercise for A levels that would be analogous to the one for GCSEs in Table 5.
} 
to be correlated with positive educational outcomes at age 16. We also find that ownership of other household assets that could proxy household wealth, such as cars, dryers, and dishwashers generally does not have the same effects on educational attainment as PCs. When we control for future ownership of a PC as a proxy for unobserveable household characteristics, the PC effects remain and the future PC variables are insignificant. All of these findings are consistent with the view that the PC effects we identify may reflect a direct role for PCs in the educational "production function" for teenagers.

Data from household surveys, where unobservables at the household and possibly even at the individual level may cause potential problems, are not the ideal way to measure the impact of PCs on educational attainment. Random assignment of individuals to control and treatment groups, could help control for unobserved effects explicitly, though this is unlikely ever to happen in the nationally important examinations we study here. Moreover, the "one-off" nature of the examinations we study, means that even an experiment would struggle to control for individual unobservable effects. So, until we are confronted with experimental evidence to the contrary, we can only conclude that the results here suggest that PC ownership may have economically and economically important effects on educational and, by extension, subsequent economic outcomes. If so, then policy makers may need to consider the implications of these effects for economic and social inequality. 


\begin{tabular}{|c|c|c|c|c|c|c|c|c|}
\hline & All & \multicolumn{4}{|c|}{ Sample of 16 year old individuals } & \multicolumn{3}{|c|}{ individuals } \\
\hline & \multicolumn{5}{|c|}{ Mean } & \multirow{3}{*}{$\begin{array}{c}\% \text { with } \\
\text { PC }\end{array}$} & \multirow{3}{*}{$\begin{array}{l}\% \text { with } \\
\text { A Level }\end{array}$} & Mean \\
\hline & & & $\%$ with & No. & $\%$ with & & & no. A \\
\hline & $\%$ with & $\%$ with & GCSE & GCSE & $5+$ & & & level \\
\hline \multirow[t]{2}{*}{ Year } & $\mathrm{PC}$ & $\mathrm{PC}$ & $A^{*}-C$ & $A^{*}-C$ & GCSE & & & passes \\
\hline & & & & passes & $A^{*}-C$ & & & \\
\hline \multirow[t]{2}{*}{1991} & 29.4 & 52.1 & 62.4 & 3.6 & 38.7 & .359 & .339 & 0.6 \\
\hline & $(0.4)$ & (2.7) & (4.3) & $(3.5)$ & $(4.4)$ & $(.027)$ & $(.036)$ & $(1.2)$ \\
\hline \multirow[t]{2}{*}{1994} & 34.4 & 52.3 & 64.2 & 4.1 & 45.1 & .463 & .488 & 1.1 \\
\hline & $(0.4)$ & $(4.1)$ & $(4.1)$ & $(3.8)$ & (4.3) & $(.037)$ & $(.041)$ & $(1.4)$ \\
\hline \multirow[t]{2}{*}{1997} & 37.4 & 51.2 & 67.6 & 4.5 & 47.7 & .554 & .482 & 1.2 \\
\hline & $(0.4)$ & (3.6) & (3.3) & $(4.0)$ & (3.8) & $(.035)$ & $(.044)$ & (1.6) \\
\hline \multirow[t]{2}{*}{2001} & 57.1 & 73.2 & 76.9 & 5.2 & 56.1 & .667 & .485 & 1.3 \\
\hline & $(0.3)$ & (2.9) & (2.3) & $(4.0)$ & (2.8) & $(.035)$ & $(.033)$ & (1.7) \\
\hline
\end{tabular}

Source: Authors' calculations using BHPS, 1991-2001. Individual PC count is percentage of individuals living in a household with a home computer present. Note mean number of passes include those coded as zero who did not take A level examination. Age cohort refer to first sample observation taken after examination. Standard deviations in brackets. 
Table 2: Effect of PC ownership at Age 15 on Educational Attainment at Age 16
(1)
(2)
(3)
(4)
(5)
(6)

(a) Any GCSE grade A*-C

$\begin{array}{ccccccc}\mathrm{PC} \text { at } 15 & 0.151^{* *} & 0.099^{* *} & 0.029 & 0.034 & 0.032 & 0.018 \\ & (0.027) & (0.027) & (0.026) & (0.026) & (0.027) & (0.028)\end{array}$

Controls

$\begin{array}{lcccccc}\text { Panel wave } & \text { Yes } & \text { Yes } & \text { Yes } & \text { Yes } & \text { Yes } & \text { Yes } \\ \text { Income } & \text { No } & \text { Yes } & \text { Yes } & \text { Yes } & \text { Yes } & \text { Yes } \\ \text { Household } & \text { No } & \text { No } & \text { Yes } & \text { Yes } & \text { Yes } & \text { Yes } \\ \text { Individual } & \text { No } & \text { No } & \text { No } & \text { Yes } & \text { Yes } & \text { Yes } \\ \text { Area } & \text { No } & \text { No } & \text { No } & \text { No } & \text { Yes } & \text { Yes } \\ \text { Area 2 } & \text { No } & \text { No } & \text { No } & \text { No } & \text { No } & \text { Yes } \\ \text { Pseudo R } & & & & & & \\ \mathrm{N} & 0.032 & 0.069 & 0.139 & 0.172 & 0.237 & 0.252 \\ & 1453 & 1453 & 1453 & 1453 & 1453 & 1305\end{array}$

(b) Number of GCSEs grade $A *-C$
$\mathrm{PC}$ at 15
$1.218 * * \quad 0.981 * *$
$0.567 * *$
$0.667 * *$
$0.548^{*}$
$0.536^{*}$
(0.235) (0.237)
$(0.233) \quad(0.226)$
(0.235)
(0.249)

Controls

$\begin{array}{lcccccc}\text { Panel wave } & \text { Yes } & \text { Yes } & \text { Yes } & \text { Yes } & \text { Yes } & \text { Yes } \\ \text { Income } & \text { No } & \text { Yes } & \text { Yes } & \text { Yes } & \text { Yes } & \text { Yes } \\ \text { Household } & \text { No } & \text { No } & \text { Yes } & \text { Yes } & \text { Yes } & \text { Yes } \\ \text { Individual } & \text { No } & \text { No } & \text { No } & \text { Yes } & \text { Yes } & \text { Yes } \\ \text { Area } & \text { No } & \text { No } & \text { No } & \text { No } & \text { Yes } & \text { Yes } \\ \text { Area 2 } & \text { No } & \text { No } & \text { No } & \text { No } & \text { No } & \text { Yes } \\ & & & & & & \\ \text { Adjusted R } & 0.035 & 0.054 & 0.154 & 0.191 & 0.205 & 0.192 \\ \text { N } & 1005 & 1005 & 1005 & 1005 & 1005 & 887 \\ & & & & & & \\ \text { (c) 5 + GCSE grade } \mathbf{A}^{*} \text {-C } & 0.151^{* *} & 0.127^{* *} & 0.084^{* *} & 0.096^{* *} & 0.086^{*} & 0.093^{*} \\ \text { PC at 15 } & (0.035) & (0.036) & (0.037) & (0.037) & (0.038) & (0.040) \\ \end{array}$




\begin{tabular}{lcccccc}
\hline Controls & & & & & & \\
Panel wave & Yes & Yes & Yes & Yes & Yes & Yes \\
Income & No & Yes & Yes & Yes & Yes & Yes \\
Household & No & No & Yes & Yes & Yes & Yes \\
Individual & No & No & No & Yes & Yes & Yes \\
Area & No & No & No & No & Yes & Yes \\
Area 2 & No & No & No & No & No & Yes \\
& & & & & & 0.172 \\
Pseudo R & 0.025 & 0.033 & 0.099 & 0.136 & 0.167 & 0.172 \\
N & 1005 & 1005 & 1005 & 1005 & 1005 & 887 \\
\hline
\end{tabular}

Notes: Analysis of BHPS 1991-2001. Robust standard errors in brackets; *, significant at 5\%; **, at 1\%.

Coefficients in panels a and $\mathrm{c}$ are marginal probabilities from p robit equations. Coefficients in panel $\mathrm{b}$ are OLS estimates. Area 2 effects in column 6 includes local authority level data and applies to England only. Standard errors adjusted for clustering at household level. 
Table 3: Effect of household assets at age 15 on Number of GCSEs at age 16 and on

likelihood of 5+ GCSES

(1)

(2)

(3)

(4)

(5)

(6)

(7)

(8)

(a) Number GCSEs A*-C

Dishwasher $\quad 0.762 * * \quad-0.016$

(0.229) (0.231)

Drier

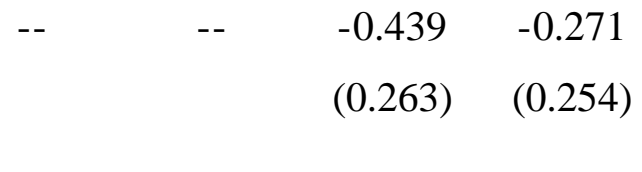

Car

PC at 15

$--$

\section{Controls}

$\begin{array}{lcccccccc}\text { Panel wave } & \text { Yes } & \text { Yes } & \text { Yes } & \text { Yes } & \text { Yes } & \text { Yes } & \text { Yes } & \text { Yes } \\ \text { Income } & \text { Yes } & \text { Yes } & \text { Yes } & \text { Yes } & \text { Yes } & \text { Yes } & \text { Yes } & \text { Yes } \\ \text { Household } & \text { No } & \text { Yes } & \text { No } & \text { Yes } & \text { No } & \text { Yes } & \text { No } & \text { Yes } \\ \text { Individual } & \text { No } & \text { Yes } & \text { No } & \text { Yes } & \text { No } & \text { Yes } & \text { No } & \text { Yes } \\ \text { Area } & \text { No } & \text { Yes } & \text { No } & \text { Yes } & \text { No } & \text { Yes } & \text { No } & \text { Yes } \\ & & & & & & & & \\ \text { Adj. R } & 0.049 & 0.200 & 0.049 & 0.201 & 0.043 & 0.202 & 0.070 & 0.206 \\ \text { N } & 1005 & 1005 & 1005 & 1005 & 1005 & 1005 & 1005 & 1005\end{array}$

(b) 5 + GCSEs A*-C

\begin{tabular}{|c|c|c|c|c|c|c|c|c|}
\hline Dishwasher & $\begin{array}{l}0.104 * * \\
(0.032)\end{array}$ & $\begin{array}{c}0.014 \\
(0.037)\end{array}$ & -- & -- & -- & -- & $\begin{array}{l}0.086 * \\
(0.034)\end{array}$ & $\begin{array}{l}0.002 \\
(0.037)\end{array}$ \\
\hline Drier & -- & -- & $\begin{array}{l}-0.053 \\
(0.038)\end{array}$ & $\begin{array}{l}-0.030 \\
(0.042)\end{array}$ & -- & -- & $\begin{array}{l}-0.099 * \\
(0.037)\end{array}$ & $\begin{array}{l}-0.050 \\
(0.041)\end{array}$ \\
\hline Car & -- & -- & -- & -- & $\begin{array}{l}0.162 * * \\
(0.060)\end{array}$ & $\begin{array}{c}0.118 \\
(0.068)\end{array}$ & $\begin{array}{l}0.141 * * \\
(0.063)\end{array}$ & $\begin{array}{l}0.128 \\
(0.070)\end{array}$ \\
\hline $\mathrm{PC}$ at 15 & -- & -- & -- & -- & -- & -- & $\begin{array}{l}0.115^{* *} \\
(0.037)\end{array}$ & $\begin{array}{c}0.090 * \\
(0.039)\end{array}$ \\
\hline
\end{tabular}

Controls 


\begin{tabular}{lcccccccc}
\hline Panel wave & Yes & Yes & Yes & Yes & Yes & Yes & Yes & Yes \\
Income & No & Yes & Yes & Yes & Yes & Yes & Yes & Yes \\
Household & No & Yes & No & Yes & No & Yes & No & Yes \\
Individual & No & Yes & No & Yes & No & Yes & No & Yes \\
Area & No & Yes & No & Yes & No & Yes & No & Yes \\
& & & & & & & & \\
Pseudo R & 0.030 & 0.160 & 0.023 & 0.164 & 0.029 & 0.163 & 0.048 & 0.172 \\
N & 1005 & 1005 & 1005 & 1005 & 1005 & 1005 & 1005 & 1005 \\
\hline
\end{tabular}

Notes: Analysis of BHPS 1991-2001. Sample size in all regressions is 1005 (observations with zero GCSEs

excluded in base category). In all cases, household asset ownership determined at time child was 15 years old.

Robust standard errors adjusted for clustering at household level in parentheses; *, significant at 5\%; **, at $1 \%$. 
Table 4: Future PC Ownership and Educational Attainment at 16

(a) Number GCSEs A*-C

$\mathrm{PC}$ at 15

$$
\begin{gathered}
0.576 * * \\
(0.237)
\end{gathered}
$$

No PC at 15

but $\mathrm{PC}$ at $16-18$

No PC at 15 but had owned at some time before

Adjusted $\mathrm{R}^{2}$

$\mathrm{N}$

$\begin{array}{lllll}0.206 & .200 & 0.206 & 0.205 & 0.206 \\ 1005 & 1005 & 1005 & 1005 & 1005\end{array}$

(b) 5 + GCSEs A*-C

$\mathrm{PC}$ at 15

$\begin{array}{llllr}0.090 * & -- & 0.098 * & 0.085 & 0.098 \\ (0.039) & & (0.042) & (0.049) & (0.059)\end{array}$

No PC at 15

but $\mathrm{PC}$ at $16-18$

No PC at 15 but had owned at some time before

\section{(1)}

$--$$$
\text { - }
$$

$-0.031$

0.033

$--$

0.034

(0.073)

(0.072)

(0.080)

(4)

(5)

(3)

$0.616^{*}$

$0.873^{*}$

(0.342)

0.715

(0.514)

0.333

$(0.438) \quad(0.459)$

$\begin{array}{lll}-- & -0.011 & 0.001 \\ & (0.064) & (0.070)\end{array}$

$\begin{array}{lccccr}\text { Pseudo R } & 0.172 & 0.167 & 0.172 & 0.172 & 0.172 \\ \mathrm{~N} & 1005 & 1005 & 1005 & 1005 & 1005\end{array}$

Notes: see Table 2. Regressions contain full set of controls as in column 8 of Table 3.

Standard errors in brackets * significant at $5 \%$;** at $1 \%$. 
Table 5: Frequency of $\mathrm{PC}$ use at 15 and Educational Attainment at 16

\begin{tabular}{|c|c|c|c|c|c|c|c|c|c|}
\hline & \multicolumn{3}{|c|}{ Any GCSE's } & \multicolumn{3}{|c|}{ Number GCSE A*-C } & \multicolumn{3}{|c|}{ 5+ GCSE's at A*-C } \\
\hline & $(0.033)$ & $(0.046)$ & & $(0.274)$ & $(0.483)$ & & $(0.047)$ & $(0.074)$ & \\
\hline Years of & 0.003 & & & 0.022 & & & 0.009 & & \\
\hline \multicolumn{10}{|l|}{ Frequency of use } \\
\hline at 15: & & -- & $-0.197 \#$ & & & 0.352 & & -- & 0.019 \\
\hline No days a week & & & $(0.122)$ & & & $(0.885)$ & & & $(0.109)$ \\
\hline \multirow[t]{2}{*}{ 1-2 days a week } & & -- & -0.017 & & & 0.236 & & -- & -0.009 \\
\hline & & & $(0.054)$ & & & $(0.566)$ & & & $(0.075)$ \\
\hline Most days each & & -- & $0.125^{*}$ & & & 0.750 & & -- & $0.118 \#$ \\
\hline week & & & $(0.035)$ & & & $(0.583)$ & & & $(0.061)$ \\
\hline Pseudo $\mathrm{R}^{2}$ & 0.238 & 0.296 & 0.329 & 0.203 & 0.172 & 0.172 & 0.172 & 0.233 & 0.233 \\
\hline $\mathrm{N}$ & 1453 & 492 & 492 & 1005 & 343 & 343 & 1005 & 343 & 343 \\
\hline
\end{tabular}

Notes: see Table 2. Estimates based on same specifications that in Appendix Table A2. Frequency regressions contain full set of controls as in column 8 of Table 3 along with additional variables for individual's attitude to school and whether bullied or not. * significant at 5\% level; \# significant at $10 \%$ level. 
Table 6: Effect of PC ownership at Age 17 on Educational Attainment at Age 18

$\begin{array}{cccc}\text { Any A Levels } & \text { Any A levels / } & \text { Number of A } & \text { 3+ A Levels } \\ & \text { 5+ GCSEs } & \text { levels } & \text { / Has A level } \\ & & \text { / Has A level } & \end{array}$

Panel A

PC at 17

$0.123 * *$

$0.109^{*}$

$0.278 *$

$0.149 * *$

(0.031)

(0.055)

(0.111)

(0.056)

Pseudo $\mathrm{R}^{2} /$ Adj. $\mathrm{R}^{2}$

0.189

0.221

0.154

0.233

$\mathrm{N}$

1512

513

471

471

Panel B

PC at 17

$0.083 *$

$(0.035)$

0.302

1364
0.081

(0.059)

0.253

497
$0.229 *$

(0.114)

$0.161 * *$

(0.062)

Pseudo $\mathrm{R}^{2} /$ Adj. $\mathrm{R}^{2}$

0.328

0.233

N

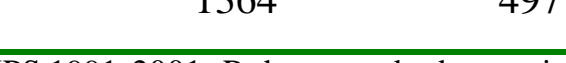

\section{Note}

clustering. * significant at 5\%;** at $1 \%$. See Table A3 for set of control variables. Estimates in columns 1, 2 and 4 are marginal probabilities from probit equations. Es timates in column 3 are OLS regression coefficients. Sample size in columns 3 and 4 less than that in column 2 because of missing values on dependent variable.

Panel B is sub-set of panel with information on number of GCSE qualifications which is included as an extra conditioning variable. 


\begin{tabular}{|c|c|c|c|c|}
\hline & $\begin{array}{l}\text { Any A } \\
\text { Levels }\end{array}$ & $\begin{array}{c}\text { Any A } \\
\text { levels / 5+ } \\
\text { GCSEs }\end{array}$ & $\begin{array}{c}\text { Number of } \\
\text { A levels } \\
\text { / Has A } \\
\text { level }\end{array}$ & $\begin{array}{c}\text { 3+ A Levels } \\
\text { / Has A } \\
\text { level }\end{array}$ \\
\hline Panel A & & & & \\
\hline $\mathrm{PC}$ at 17 & $\begin{array}{c}0.144 * * \\
(0.032)\end{array}$ & $\begin{array}{c}0.129 * * \\
(0.059)\end{array}$ & $\begin{array}{c}0.286^{* *} \\
(0.128)\end{array}$ & $\begin{array}{c}0.168 * * \\
(0.067)\end{array}$ \\
\hline No $P C$ at 17 but $P C$ at $18-20$ & $\begin{array}{c}0.102 * * \\
(0.051)\end{array}$ & $\begin{array}{r}0.084 \\
(0.076)\end{array}$ & $\begin{array}{c}0.025 \\
(0.207)\end{array}$ & $\begin{array}{c}0.049 \\
(0.070)\end{array}$ \\
\hline Pseudo $\mathrm{R}^{2}$ / Adj. $\mathrm{R}^{2}$ & 0.190 & 0.222 & 0.153 & 0.234 \\
\hline $\mathrm{N}$ & 1512 & 513 & 471 & 471 \\
\hline $\mathrm{PC}$ at 17 & $\begin{array}{l}0.189 * * \\
(0.042)\end{array}$ & $\begin{array}{c}0.129 \\
(0.091)\end{array}$ & $\begin{array}{c}0.150 \\
(0.191)\end{array}$ & $\begin{array}{l}0.151 \# \\
(0.098)\end{array}$ \\
\hline No $P C$ at 17 but $P C$ at $18-20$ & $\begin{array}{c}0.139 * * \\
(0.055)\end{array}$ & $\begin{array}{r}0.084 \\
(0.087)\end{array}$ & $\begin{array}{l}-0.105 \\
(0.245)\end{array}$ & $\begin{array}{c}0.037 \\
(0.090)\end{array}$ \\
\hline No PC at 17 but had before & $\begin{array}{l}0.091 \# \\
(0.055)\end{array}$ & $\begin{array}{r}0.001 \\
(0.095)\end{array}$ & $\begin{array}{l}-0.195 \\
(0.228)\end{array}$ & $\begin{array}{l}-0.024 \\
(0.103)\end{array}$ \\
\hline Pseudo $\mathrm{R}^{2} /$ Adj. $\mathrm{R}^{2}$ & 0.191 & 0.222 & 0.153 & 0.234 \\
\hline $\mathrm{N}$ & 1512 & 513 & 471 & 471 \\
\hline Panel B & & & & \\
\hline $\mathrm{PC}$ at 17 & $\begin{array}{c}0.105 * * \\
(0.037)\end{array}$ & $\begin{array}{c}0.098 \\
(0.063)\end{array}$ & $\begin{array}{l}0.254 \# \\
(0.131)\end{array}$ & $\begin{array}{c}0.181 * * \\
(0.072)\end{array}$ \\
\hline No $P C$ at 17 but $P C$ at $18-20$ & $\begin{array}{l}0.102 * * \\
(0.057)\end{array}$ & $\begin{array}{r}0.081 \\
(0.081)\end{array}$ & $\begin{array}{r}0.077 \\
(0.214)\end{array}$ & $\begin{array}{c}0.043 \\
(0.075)\end{array}$ \\
\hline Pseudo $\mathrm{R}^{2} /$ Adj. $\mathrm{R}^{2}$ & 0.304 & 0.254 & 0.336 & 0.287 \\
\hline $\mathrm{N}$ & 1364 & 497 & 428 & 428 \\
\hline
\end{tabular}




\begin{tabular}{lcccc}
\hline PC at 17 & $0.143^{* *}$ & 0.073 & 0.181 & $0.132 \#$ \\
No PC at 17 but PC at 18-20 & $(0.048)$ & $(0.093)$ & $(0.188)$ & $(0.102)$ \\
& $0.134 * *$ & 0.066 & -0.074 & 0.008 \\
No PC at 17 but had before & $(0.063)$ & $(0.096)$ & $(0.243)$ & $(0.103)$ \\
& 0.079 & -0.036 & -0.162 & -0.072 \\
Pseudo R ${ }^{2} /$ Adj. R & $(0.062)$ & $(0.106)$ & $(0.226)$ & $(0.119)$ \\
N & & & & \\
\hline
\end{tabular}

Notes: See Table 6. Analysis of BHPS 1991-2001. Panel B is sub-set of panel with information on number of GCSE qualifications which is included as an extra conditioning variable.

Mean of dependent variable is 2.9 in column 3 (panel B); 0.72 in column 4 (panel B). 


\begin{tabular}{|c|c|c|c|c|}
\hline \multirow[b]{2}{*}{ Individual Characteristics } & \multicolumn{2}{|c|}{16 year olds } & \multicolumn{2}{|c|}{18 year olds } \\
\hline & Mean & s.error & Mean & s.error \\
\hline Female & 0.491 & 0.013 & 0.437 & 0.012 \\
\hline Enter $2^{\text {nd }}$ third of school year & 0.352 & 0.013 & 0.344 & 0.012 \\
\hline Enter $3^{\text {rd }}$ third of school year & 0.371 & 0.013 & 0.331 & 0.012 \\
\hline White & 0.884 & 0.008 & 0.888 & 0.008 \\
\hline Sibling order - is $1^{\text {st }}$ child & 0.569 & 0.013 & 0.636 & 0.013 \\
\hline Sibling order - is $2^{\text {nd }}$ child & 0.341 & 0.012 & 0.292 & 0.012 \\
\hline Sibling order - is $3^{\text {rd }}$ child & 0.077 & 0.007 & 0.061 & 0.006 \\
\hline Sibling order - is $4^{\text {th }}+$ child & 0.013 & 0.003 & 0.011 & 0.003 \\
\hline Good Health & 0.239 & 0.011 & 0.247 & 0.011 \\
\hline \multicolumn{5}{|l|}{ Parental Characteristics } \\
\hline Father Graduate & 0.192 & 0.010 & 0.131 & 0.010 \\
\hline Father A levels & 0.313 & 0.012 & 0.325 & 0.012 \\
\hline Father Technical & 0.134 & 0.009 & 0.148 & 0.010 \\
\hline Father GCSE & 0.140 & 0.009 & 0.198 & 0.011 \\
\hline Father none & 0.221 & 0.011 & 0.198 & 0.011 \\
\hline Mother Graduate & 0.153 & 0.010 & 0.153 & 0.010 \\
\hline Mother A levels & 0.366 & 0.012 & 0.369 & 0.012 \\
\hline Mother Technical & 0.234 & 0.011 & 0.245 & 0.011 \\
\hline Mother GCSE & 0.197 & 0.010 & 0.186 & 0.010 \\
\hline Mother none & 0.050 & 0.006 & 0.047 & 0.005 \\
\hline Father's Age & 45.8 & 7.9 & 47.5 & 6.3 \\
\hline Mother's Age & 43.0 & 4.3 & 44.4 & 5.6 \\
\hline Parent-Teacher association member & 0.099 & 0.008 & 0.054 & 0.006 \\
\hline Father religious & 0.046 & 0.006 & 0.032 & 0.006 \\
\hline Parent's perceive "bad" neighbourhood & 0.081 & 0.007 & 0.062 & 0.006 \\
\hline No Father info. & 0.302 & 0.012 & 0.303 & 0.012 \\
\hline No mother info. & 0.076 & 0.007 & 0.119 & 0.008 \\
\hline \multicolumn{5}{|l|}{ Household Characteristics } \\
\hline Real equivalized household income & 14,741 & 11,775 & 15,548 & 10,751 \\
\hline Number of rooms & 5.3 & 1.6 & 4.6 & 2.2 \\
\hline
\end{tabular}




\begin{tabular}{lllll}
\hline Number dependent children & 0.877 & 1.042 & 0.576 & 0.869 \\
Local authority housing & 0.200 & 0.011 & 0.191 & 0.010 \\
Private rental housing & 0.051 & 0.006 & 0.134 & 0.010 \\
Moved in last 12 months & 0.049 & 0.006 & 0.079 & 0.007 \\
PC & 0.659 & 0.012 & 0.600 & 0.013 \\
Dishwasher & 0.426 & 0.013 & 0.423 & 0.013 \\
Tumble Drier & 0.792 & 0.011 & 0.781 & 0.010 \\
Car & 0.895 & 0.008 & 0.890 & 0.008 \\
Area Characteristics & & & & \\
\% free-school meals & 11.7 & 7.6 & 11.7 & 7.3 \\
Pupil-Teacher ratio & 18.1 & 1.2 & 18.0 & 1.2 \\
Average pupil funding (£ 2002) & 2945 & 436 & 2939 & 414 \\
Grammar school & 0.054 & 0.006 & 0.051 & 0.006 \\
Private school & 0.050 & 0.006 & 0.059 & 0.006 \\
Secondary modern & 0.134 & 0.009 & 0.145 & 0.010 \\
Other non-comprehensive school & 0.042 & 0.005 & 0.046 & 0.005 \\
\hline Note sampleproporton & & & & \\
\hline
\end{tabular}

Note: sample proportion standard errors used for dummy variables. Income variables in 2002 prices. 
Table A2: Full Specifications : Educational Attainment at 16

\begin{tabular}{|c|c|c|c|}
\hline & Any GCSEs & Number of GCSEs & Five + GCSEs \\
\hline \multirow[t]{2}{*}{$\mathrm{PC}$ at 15} & 0.032 & $0.576^{*}$ & $0.090 *$ \\
\hline & $(0.027)$ & $(0.237)$ & $(0.039)$ \\
\hline \multirow[t]{2}{*}{ Dishwasher at 15} & 0.008 & -0.053 & 0.002 \\
\hline & $(0.030)$ & $(0.238)$ & $(0.037)$ \\
\hline \multirow[t]{2}{*}{ Car at 15} & -0.005 & 0.485 & $0.128 \#$ \\
\hline & $(0.042)$ & $(0.405)$ & $(0.070)$ \\
\hline \multirow[t]{2}{*}{ Washer/Dryer at 15} & -0.016 & -0.350 & -0.050 \\
\hline & $(0.032)$ & $(0.259)$ & $(0.041)$ \\
\hline Real Household & $4.39 \mathrm{e}^{-6}$ & $0.244 \mathrm{e}-4$ & $0.132 \mathrm{e}-5$ \\
\hline Income & $\left(2.35 \mathrm{e}^{-6}\right)$ & $(0.946 e-5)$ & $(0.278 \mathrm{e}-6)$ \\
\hline \multirow[t]{2}{*}{ Income $^{2}$} & $-1.89^{\mathrm{e}-11}$ & $0.226 \mathrm{e}-9$ & $0.211 \mathrm{e}-10$ \\
\hline & $\left(1.90 \mathrm{e}^{-11}\right)$ & $(0.913 \mathrm{e}-10)$ & $(0.223 \mathrm{e}-10)$ \\
\hline \multirow[t]{2}{*}{ Income missing } & $0.202 * *$ & 1.789 & 0.126 \\
\hline & $(0.027)$ & $(2.156)$ & $(0.210)$ \\
\hline \multirow[t]{2}{*}{ Father's age (yrs) } & 0.001 & 0.009 & 0.002 \\
\hline & $(0.001)$ & $(0.010)$ & $(0.002)$ \\
\hline \multirow[t]{2}{*}{ Mother's age (yrs) } & $0.003 *$ & $0.039 * *$ & $0.005 * *$ \\
\hline & $(0.001)$ & $(0.013)$ & $(0.002)$ \\
\hline \multicolumn{4}{|l|}{ Father's education: } \\
\hline Higher Intermediate & -0.043 & $-0.770 *$ & -0.085 \\
\hline \multirow[t]{2}{*}{ Intermediate } & $(0.048)$ & $(0.326)$ & $(0.060)$ \\
\hline & -0.100 & $-0.780 *$ & -0.052 \\
\hline \multirow[t]{2}{*}{ Lower intermediate } & $(0.061)$ & $(0.386)$ & $(0.070)$ \\
\hline & -0.094 & $-1.780 * *$ & $-0.237 * *$ \\
\hline \multirow[t]{2}{*}{ None/missing } & $(0.057)$ & $(0.405)$ & $(0.078)$ \\
\hline & -0.014 & $-1.390 * *$ & $-0.213 * *$ \\
\hline Mother's education & $(0.059)$ & $(0.396)$ & $(0.075)$ \\
\hline \multirow[t]{2}{*}{ Higher Intermediate } & -0.073 & $-0.722 *$ & $-0.120 *$ \\
\hline & $(0.048)$ & $(0.293)$ & $(0.053)$ \\
\hline Intermediate & -0.040 & $-0.688^{*}$ & $-0.145^{*}$ \\
\hline
\end{tabular}




\begin{tabular}{|c|c|c|c|}
\hline & $(0.051)$ & $(0.326)$ & $(0.060)$ \\
\hline \multirow[t]{2}{*}{ Lower intermediate } & $-0.182 * *$ & $-0.865^{*}$ & $-0.160 *$ \\
\hline & $(0.060)$ & $(0.388)$ & $(0.071)$ \\
\hline \multirow[t]{2}{*}{ None/missing } & -0.010 & -0.556 & -0.039 \\
\hline & $(0.086)$ & $(0.687)$ & $(0.109)$ \\
\hline Parent member of & $0.086 *$ & $0.886^{* *}$ & $0.138 * *$ \\
\hline school association & $(0.039)$ & $(0.288)$ & $(0.044)$ \\
\hline \multirow[t]{2}{*}{ Father religious } & $0.084 \#$ & 0.394 & 0.096 \\
\hline & $(0.050)$ & $(0.380)$ & $(0.066)$ \\
\hline \multirow[t]{2}{*}{ No father } & -0.007 & $1.083^{*}$ & $0.167 *$ \\
\hline & $(0.054)$ & $(0.490)$ & $(0.065)$ \\
\hline \multirow[t]{2}{*}{ No mother } & -0.033 & 1.032 & 0.071 \\
\hline & $(0.071)$ & $(0.696)$ & $(0.088)$ \\
\hline Number of children in & -0.011 & -0.033 & 0.006 \\
\hline household & $(0.013)$ & $(0.117)$ & $(0.020)$ \\
\hline \multirow[t]{2}{*}{ Sibling order: $2^{\text {nd }}$} & $-0.063 *$ & $-0.542 * *$ & $-0.093 * *$ \\
\hline & $(0.028)$ & $(0.205)$ & $(0.035)$ \\
\hline \multirow[t]{2}{*}{ Sibling order: $3^{\text {rd }}$} & $-0.216^{* *}$ & -0.667 & $-0.129 \#$ \\
\hline & $(0.058)$ & $(0.409)$ & $(0.073)$ \\
\hline \multirow[t]{2}{*}{ Sibling order: $4^{\text {th }}+$} & -0.059 & -1.133 & -0.220 \\
\hline & $(0.131)$ & $(0.802)$ & $(0.158)$ \\
\hline Household moved last & 0.011 & -0.247 & -0.024 \\
\hline 12 months & $(0.051)$ & $(0.419)$ & $(0.078)$ \\
\hline \multirow[t]{2}{*}{ Female } & $0.093 * *$ & $1.154 * *$ & $0.164 * *$ \\
\hline & $(0.024)$ & $(0.190)$ & $(0.031)$ \\
\hline \multirow[t]{2}{*}{ White } & 0.024 & $-0.883 \#$ & $-0.151 *$ \\
\hline & $(0.061)$ & $(0.457)$ & $(0.061)$ \\
\hline \multirow[t]{2}{*}{ Ethnicity missing } & $-0.434 * *$ & -0.671 & -0.105 \\
\hline & $(0.092)$ & $(0.799)$ & $(0.175)$ \\
\hline \multirow[t]{2}{*}{ Born $2^{\text {nd }}$ trimester } & 0.006 & 0.291 & 0.006 \\
\hline & $(0.031)$ & $(0.250)$ & $(0.040)$ \\
\hline \multirow[t]{2}{*}{ Born $3^{\text {rd }}$ trimester } & 0.010 & -0.018 & -0.028 \\
\hline & $(0.032)$ & $(0.249)$ & $(0.040)$ \\
\hline
\end{tabular}




\begin{tabular}{|c|c|c|c|}
\hline \multirow[t]{2}{*}{ Good Health } & $0.063 *$ & $0.396 \#$ & $0.080 *$ \\
\hline & $(0.026)$ & $(0.213)$ & $(0.034)$ \\
\hline \multirow{2}{*}{$\begin{array}{l}\text { Parental attitude to } \\
\text { area is "bad" }\end{array}$} & -0.061 & 0.420 & 0.062 \\
\hline & $(0.044)$ & $(0.360)$ & $(0.053)$ \\
\hline \multirow[t]{2}{*}{ No. rooms in house } & 0.009 & $0.226^{* *}$ & $0.019 \#$ \\
\hline & $(0.008)$ & $(0.062)$ & $(0.011)$ \\
\hline \multirow[t]{2}{*}{ Council housing } & $-0.163 * *$ & -0.428 & -0.013 \\
\hline & $(0.042)$ & $(0.346)$ & $(0.056)$ \\
\hline \multirow[t]{2}{*}{ Private rental } & -0.002 & 0.189 & 0.065 \\
\hline & $(0.059)$ & $(0.432)$ & $(0.067)$ \\
\hline \multirow[t]{2}{*}{ Grammar school } & 0.061 & $1.058 * *$ & $0.111 \#$ \\
\hline & $(0.057)$ & $(0.381)$ & $(0.057)$ \\
\hline \multirow[t]{2}{*}{ Private school } & -0.056 & -0.156 & 0.013 \\
\hline & $(0.072)$ & $(0.399)$ & $(0.073)$ \\
\hline \multirow[t]{2}{*}{ Secondary modern } & $-0.163 * *$ & $-0.819 *$ & $-0.118^{*}$ \\
\hline & $(0.043)$ & $(0.325)$ & $(0.055)$ \\
\hline \multirow{2}{*}{$\begin{array}{l}\text { Other non- } \\
\text { comprehensive }\end{array}$} & $-0.349 * *$ & -0.709 & -0.147 \\
\hline & $(0.074)$ & $(0.690)$ & $(0.116)$ \\
\hline Observations & 1453 & 1005 & 1005 \\
\hline R-squared & 0.24 & 0.24 & 0.16 \\
\hline
\end{tabular}


Table A3: Full Specifications : Educational Attainment at 18

\begin{tabular}{|c|c|c|c|c|}
\hline & Any A Levels & $\begin{array}{c}\text { Any A levels / } \\
\text { 5+ GCSEs }\end{array}$ & $\begin{array}{c}\text { Number of } \mathrm{A} \\
\text { levels }\end{array}$ & $3+$ A Levels \\
\hline \multirow[t]{2}{*}{ PC at 17} & $0.124 * *$ & $0.109^{*}$ & $0.278^{*}$ & $0.149 * *$ \\
\hline & $(0.031)$ & $(0.053)$ & $(0.108)$ & $(0.056)$ \\
\hline \multirow[t]{2}{*}{ Dishwasher at 17} & -0.004 & -0.041 & -0.065 & -0.080 \\
\hline & $(0.033)$ & $(0.052)$ & $(0.104)$ & $(0.046)$ \\
\hline \multirow{2}{*}{ Dryer at 17} & 0.053 & 0.090 & 0.198 & $0.149^{*}$ \\
\hline & $(0.038)$ & $(0.064)$ & $(0.126)$ & $(0.064)$ \\
\hline \multirow[t]{2}{*}{ Car at 17} & -0.034 & -0.104 & -0.136 & -0.073 \\
\hline & $(0.053)$ & $(0.076)$ & $(0.216)$ & $(0.092)$ \\
\hline \multirow[t]{2}{*}{ VCR at 17} & -0.084 & 0.071 & -0.048 & 0.038 \\
\hline & $(0.081)$ & $(0.130)$ & $(0.278)$ & $(0.146)$ \\
\hline \multirow[t]{2}{*}{ Real Income } & $0.588 \mathrm{e}-5^{*}$ & $-0.322 e-5$ & $-0.301 e-5$ & $-0.869 e-6$ \\
\hline & $(0.252 \mathrm{e}-5)$ & $(0.696 \mathrm{e}-5)$ & $(0.123 e-4)$ & $(0.584 \mathrm{e}-5)$ \\
\hline \multirow[t]{2}{*}{ Income $^{2}$} & $-0.602 \mathrm{e}-10^{*}$ & $0.123 e-9$ & $0.127 \mathrm{e}-10$ & $0.617 \mathrm{e}-10$ \\
\hline & $(0.242 \mathrm{e}-10)$ & $(0.127 e-9)$ & $(0.200 \mathrm{e}-10)$ & $(0.980 \mathrm{e}-10)$ \\
\hline \multirow[t]{2}{*}{ Income missing } & $0.422 * *$ & $0.265 * *$ & 0.189 & 0.105 \\
\hline & $(0.056)$ & $(0.037)$ & $(0.185)$ & $(0.065)$ \\
\hline \multirow[t]{2}{*}{ Father's age (yrs) } & 0.000 & -0.001 & -0.001 & 0.000 \\
\hline & $(0.001)$ & $(0.002)$ & $(0.004)$ & $(0.002)$ \\
\hline \multirow[t]{2}{*}{ Mother's age (yrs) } & 0.000 & -0.001 & 0.004 & -0.001 \\
\hline & $(0.001)$ & $(0.002)$ & $(0.005)$ & $(0.002)$ \\
\hline \multicolumn{5}{|l|}{ Father's education: } \\
\hline \multirow[t]{2}{*}{ Higher Intermediate } & $-0.104 *$ & -0.001 & -0.182 & $-0.170^{*}$ \\
\hline & $(0.048)$ & $(0.069)$ & $(0.120)$ & $(0.071)$ \\
\hline \multirow[t]{2}{*}{ Intermediate } & $-0.169 * *$ & -0.044 & $-0.316^{*}$ & $-0.261 *$ \\
\hline & $(0.051)$ & $(0.088)$ & $(0.157)$ & $(0.104)$ \\
\hline \multirow[t]{2}{*}{ Lower intermediate } & $-0.150 * *$ & -0.040 & -0.267 & $-0.261^{*}$ \\
\hline & $(0.053)$ & $(0.097)$ & $(0.183)$ & $(0.112)$ \\
\hline \multirow[t]{2}{*}{ None/missing } & -0.092 & -0.001 & $-0.488 * *$ & $-0.392 * *$ \\
\hline & $(0.058)$ & $(0.090)$ & $(0.165)$ & $(0.111)$ \\
\hline Mother's education: & & & & \\
\hline
\end{tabular}




\begin{tabular}{|c|c|c|c|c|}
\hline \multirow[t]{2}{*}{ Higher Intermediate } & $-0.103 *$ & -0.103 & $-0.293^{*}$ & -0.117 \\
\hline & $(0.045)$ & $(0.066)$ & $(0.124)$ & $(0.064)$ \\
\hline \multirow[t]{2}{*}{ Intermediate } & -0.092 & -0.135 & -0.133 & -0.030 \\
\hline & $(0.047)$ & $(0.079)$ & $(0.152)$ & $(0.069)$ \\
\hline \multirow[t]{2}{*}{ Lower intermediate } & $-0.137 * *$ & -0.070 & -0.323 & -0.116 \\
\hline & $(0.050)$ & $(0.093)$ & $(0.184)$ & $(0.093)$ \\
\hline \multirow[t]{2}{*}{ None/missing } & -0.018 & -0.062 & -0.446 & $-0.349 *$ \\
\hline & $(0.084)$ & $(0.141)$ & $(0.266)$ & $(0.161)$ \\
\hline \multirow{2}{*}{$\begin{array}{l}\text { Parent member of } \\
\text { school association }\end{array}$} & 0.016 & -0.086 & 0.111 & 0.089 \\
\hline & $(0.063)$ & $(0.101)$ & $(0.170)$ & $(0.066)$ \\
\hline \multirow[t]{2}{*}{ Father religious } & 0.042 & $0.159 *$ & 0.268 & 0.072 \\
\hline & $(0.083)$ & $(0.070)$ & $(0.174)$ & $(0.078)$ \\
\hline \multirow[t]{2}{*}{ No father } & -0.064 & -0.099 & 0.065 & 0.042 \\
\hline & $(0.053)$ & $(0.094)$ & $(0.184)$ & $(0.086)$ \\
\hline \multirow[t]{2}{*}{ No mother } & -0.116 & -0.115 & 0.026 & -0.015 \\
\hline & $(0.060)$ & $(0.126)$ & $(0.263)$ & $(0.116)$ \\
\hline \multirow{2}{*}{$\begin{array}{l}\text { Number of children } \\
\text { in household }\end{array}$} & $-0.057 * *$ & -0.053 & -0.075 & $-0.083^{*}$ \\
\hline & $(0.019)$ & $(0.029)$ & $(0.073)$ & $(0.033)$ \\
\hline \multirow[t]{2}{*}{ Sibling order: $2^{\text {nd }}$} & $-0.088 * *$ & $-0.166 * *$ & -0.047 & -0.003 \\
\hline & $(0.032)$ & $(0.053)$ & $(0.104)$ & $(0.048)$ \\
\hline \multirow[t]{2}{*}{ Sibling order: $3^{\text {rd }}$} & $-0.203 * *$ & $-0.291 *$ & 0.094 & 0.054 \\
\hline & $(0.053)$ & $(0.113)$ & $(0.193)$ & $(0.097)$ \\
\hline \multirow[t]{2}{*}{ Sibling order: $4^{\text {th }}+$} & -0.140 & -0.159 & $-1.201 * *$ & --- \\
\hline & $(0.136)$ & $(0.239)$ & $(0.367)$ & \\
\hline Household moved & -0.041 & 0.066 & -0.210 & -0.097 \\
\hline last 12 months & $(0.059)$ & $(0.085)$ & $(0.232)$ & $(0.121)$ \\
\hline \multirow[t]{2}{*}{ Female } & $0.096 * *$ & 0.065 & -0.031 & 0.046 \\
\hline & $(0.029)$ & $(0.047)$ & $(0.093)$ & $(0.044)$ \\
\hline \multirow[t]{2}{*}{ White } & 0.026 & 0.081 & $0.377 *$ & 0.031 \\
\hline & $(0.069)$ & $(0.110)$ & $(0.176)$ & $(0.096)$ \\
\hline \multirow[t]{2}{*}{ Ethnicity missing } & -0.134 & $0.254 * *$ & 0.087 & 0.070 \\
\hline & $(0.084)$ & $(0.037)$ & $(0.247)$ & $(0.115)$ \\
\hline Born $2^{\text {nd }}$ trimester & 0.010 & -0.022 & -0.137 & -0.032 \\
\hline
\end{tabular}




\begin{tabular}{|c|c|c|c|c|}
\hline & $(0.035)$ & $(0.051)$ & $(0.101)$ & $(0.053)$ \\
\hline \multirow[t]{2}{*}{ Born $3^{\text {rd }}$ trimester } & 0.047 & 0.090 & -0.175 & -0.054 \\
\hline & $(0.035)$ & $(0.051)$ & $(0.112)$ & $(0.053)$ \\
\hline \multirow[t]{2}{*}{ Good Health } & $0.084 *$ & $0.102 *$ & -0.031 & 0.065 \\
\hline & $(0.033)$ & $(0.043)$ & $(0.098)$ & $(0.043)$ \\
\hline Parental attitude to & -0.040 & 0.056 & -0.344 & -0.224 \\
\hline area is "bad" & $(0.054)$ & $(0.091)$ & $(0.222)$ & $(0.128)$ \\
\hline \multirow[t]{2}{*}{ No. rooms in house } & $0.041 * *$ & $0.054 * *$ & 0.003 & 0.014 \\
\hline & $(0.008)$ & $(0.012)$ & $(0.020)$ & $(0.011)$ \\
\hline \multirow[t]{2}{*}{ Council housing } & $-0.149 * *$ & $-0.231 *$ & 0.003 & $0.150 * *$ \\
\hline & $(0.041)$ & $(0.100)$ & $(0.211)$ & $(0.058)$ \\
\hline \multirow[t]{2}{*}{ Private rental } & $0.118^{*}$ & -0.020 & 0.153 & -0.013 \\
\hline & $(0.056)$ & $(0.093)$ & $(0.180)$ & $(0.099)$ \\
\hline \multirow[t]{2}{*}{ Grammar school } & 0.128 & 0.105 & $0.500 * *$ & $0.156 * *$ \\
\hline & $(0.067)$ & $(0.072)$ & $(0.166)$ & $(0.046)$ \\
\hline \multirow[t]{2}{*}{ Private school } & 0.122 & $0.160^{*}$ & $0.370 * *$ & $0.209 * *$ \\
\hline & $(0.063)$ & $(0.073)$ & $(0.130)$ & $(0.033)$ \\
\hline \multirow[t]{2}{*}{ Secondary modern } & -0.030 & 0.053 & -0.179 & -0.083 \\
\hline & $(0.041)$ & $(0.058)$ & $(0.162)$ & $(0.076)$ \\
\hline Observations & 1512 & 513 & 471 & 471 \\
\hline R-squared & 0.189 & 0.221 & 0.27 & 0.233 \\
\hline
\end{tabular}

Robust standard errors in parentheses * significant at 5\%; ** significant at $1 \%$ 


\section{References}

Anger, Silke. and Schwarze, Johannes. 2002. "Does Future PC Use Determine Our Wages Today?" IZA Discussion Paper No. 429, February, Bonn: IZA.

Angrist, Joshua and Kreuger, Alan, 1991, "Does Compulsory School Attendance Affect Schooling and Earnings?” Quarterly Journal of Economics, vol. 106, pp. 979-1014.

Angrist, Joshua and Lavy, Victor. 2002. "New Evidence on Classroom Computers and Pupil Learning," Economic Journal, October, vol. 112, pp. 735-765.

Bell, Brian, 1996. "Skill-Biased Technical Change and Wages: Evidence from a Longitudinal Data Set," The Labour Market Consequences of Technical and Structural Change Discussion Paper No. 8, Nuffield College, University of Oxford.

DiNardo, John E. and Pischke, Jörn-Steffen. 1997. "The Returns to Computer Use Revisited: Have Pencils Changed the Wage Structure too?" Quarterly Journal of Economics, vol. 112 no. 1, pp. 291-303.

Entrorf, Horst, Gollac, Michel and Francis Kramarz. 1999. "New Technologies, Wages and Worker Selection”, Journal of Labor Economics, Vol. 17, pp.464-91.

Haisken-DeNew, J. and Schmitt, C., (2001), 'Brothers in RAMS. Diffusion of the PC and the New Economy', University of Heidelberg Economics Department Working Paper.

Kominski, Robert and Eric Newburger. 1999. "Access Denied: Changes in Computer Ownership and Use: 1984-1997," Paper presented at the American Sociological Association meetings, Chicago.

Krueger, Alan. 1993. "How Computers Have Changed the Wage Structure: Evidence From Microdata, 1984-1989," Quarterly Journal of Economics, 108, No. 1, pp. 33-61.

Office of the e-Envoy. 2002. UK online: annual report 2002. http://www.e-envoy.gov.uk/oee/oee.nsf/sections/esummit-ukoannreppdf/\$file/annualreport02.pdf.

Office of National Statistics. 2002. "Internet Access: Households and Individuals," http://www.statistics.gov.uk/pdfdir/inta1202.pdf.

Schmitt, John and Jonathan Wadsworth. 2002. "Give PCs a Chance: Personal Computer Ownership and the Digital Divide in the United States and Great Britain," Centre for Economic Performance Discussion Paper No. 526.

US Department of Commerce, Economics and Statistics Administration, National Telecommunications and Information Administration. 2000. Falling Through the Net: Toward Digital Inclusion. http://www.ntia.doc.gov/ntiahome/fttn00/contents00.html. 
US Department of Commerce, Economics and Statistics Administration, National

Telecommunications and Information Administration. 2002. A Nation Online: How Americans are Expanding Their Use of the Internet.

http://www.ntia.doc.gov/ntiahome/dn/html/anationonline2.htm. 


\section{CENTRE FOR ECONOMIC PERFORMANCE \\ Recent Discussion Papers}

624 Andrew Neal

Michael A. West

Malcolm G. Patterson

623 Michele Pellizzari

622 Steven McIntosh

621 Steven McIntosh

620 David Marsden

619 Alan Manning

618 Mari Kangasniemi

L. Alan Winters

Simon Commander

617 Vicentre CuZat

Maria Guadalupe

616 James Harrigan

Anthony J. Venables

615 Howard Gospel

Paul Willman

614 Andrew B. Bernard

Stephen Redding

Peter K. Schott

Helen Simpson
Do Organisational Climate and Strategic Orientation Moderate the Relationship Between Human Resource Management Practices and Productivity?

Do Friends and Relatives Really Help in Getting a Good Job?

The Returns to Apprenticeship Training

The Impact of Vocational Qualifications on the Labour Market Outcomes of Low-Achieving School Leavers

The 'Network Economy' and Models of the Employment Contract: Psychological, Economic and Legal

Instrumental Variables for Binary Treatments with Heterogeneous Treatment Effects: A Simple Exposition

Is the Medical Brain Drain Beneficial? Evidence from Overseas Doctors in the UK

Executive Compensation and Product Market Competition

Timelines, Trade and Agglomeration

Comparatively Open: Statutory Information Disclosure for Consultation and Bargaining in Germany, France and the UK

Relative Wage Variation and Industry Location

Unions and Procedural Justice: An Alternative to the Common Rule 
612 David G. Blanchflower Alex Bryson

611 Stephen Gibbons Stephen Machin

610 Johannes Hörner

L.Rachel Ngai

Claudia Olivetti

609 Nikolaus Wolf

608 Ellen E. Meade

David Stasavage

607 Ghazala Azmat

Maia Güell

Alan Manning

606 Henry G. Overman

L. Alan Winters

605 Stephen Machin

Stephen Wood

604 Maarten Goos

Alan Manning

603 Nan-Kuang Chen

Hsiao-Lei Chu

602 Ricardo Peccei

Helen Bewley

Howard Gospel

Paul Willman
The Union Wage Premium in the US and the UK

Valuing Rail Access Using Transport Innovation

Public Enterprises and Labor Market Performance

Endowments, Market Potential, and Industrial Location: Evidence from Interwar Poland (1918-1939)

Publicity of Debate and the Incentive to Dissent:

Evidence from the US Federal Reserve

Gender Gaps in Unemployment Rates in OECD Countries

The Geography of UK International Trade

Looking for HRM/Union Substitution: Evidence from British Workplaces

Lousy and Lovely Jobs: the Rising Polarization of Work in Britain

Collateral Value and Forbearance Lending

Is it Good To Talk? Information Disclosure and Organisational Performance in the UK Incorporating evidence submitted on the DTI discussion paper 'High Performance Workplaces Informing and Consulting Employees'

The Centre for Economic Performance Publications Unit Tel 02079557673 Fax 02079557595 Email info@cep.lse.ac.uk Web site http://cep.lse.ac.uk 